\title{
Temperature and time effect of thermal aging treatment on microstructure and corrosion resistance of UNS S31803 duplex stainless steel
}

\author{
Efeito da temperatura e do tempo de tratamento térmico de envelhecimento na microestrutura e \\ resistência à corrosão do aço inoxidável duplex UNS S31803 \\ Efecto de la temperatura y del tiempo del tratamiento térmico de envejecimiento en la \\ microestructura y la resistencia a la corrosión del acero inoxidable dúplex UNS S31803
}

\begin{abstract}
Duplex stainless steels correspond to a class of steel in which the microstructure is composed basically by the phases ferrite and austenite. Given the metastable character of ferrite, associated phase transformations can occur during thermal treatments, which can lead to a reduction in corrosion resistance. Therefore, the aim of this work was to evaluate the influence of the solution-treated at $1100^{\circ} \mathrm{C}$ for $30 \mathrm{~min}$ and aging at 500 and $600^{\circ} \mathrm{C}$ for 1,3 and $12 \mathrm{~h}$, on the microstructure and corrosion resistance of DSS UNS S31803. The steels were characterized by SEM, EDS, XRD, hardness, microhardness and thermal analysis. The steels aged at $500^{\circ} \mathrm{C}$ for $1 \mathrm{~h}$ presented the phase alpha line dispersed in the ferrite, and the steels aged at $600^{\circ} \mathrm{C}$ for $12 \mathrm{~h}$ presented the phases alpha line, sigma and chi. In the assays of double cycle potentiodynamic reactivation in solution of $0.5 \mathrm{M} \mathrm{H}_{2} \mathrm{SO}_{4}$ and $0.01 \mathrm{M} \mathrm{KSNC}$, it was observed that no sensitization occurred. Furthermore, in the tests of cyclic potentiodynamic polarization, in $3.5 \% \mathrm{NaCl}$ solution, it was verified that the precipitation of the alpha line phase did not alter corrosion resistance; nevertheless, the sigma phase reduced corrosion resistance.
\end{abstract}

Keywords: Duplex stainless steel; Corrosion; Phase transformation; Aging.

\section{Resumo}

Aços inoxidáveis duplex (AID) correspondem à uma classe de aço em que a microestrutura é composta basicamente pelas fases ferrita e austenita. E devido ao caráter metaestável da ferrita, transformações de fases associadas podem ocorrer durante tratamentos térmicos como alfa linha e sigma, as quais podem levar a diminuição da resistência à corrosão. Dessa forma, o objetivo deste trabalho foi avaliar a influência dos tratamentos térmicos de solubilização a $1100^{\circ} \mathrm{C}$ por $30 \mathrm{~min}$ e envelhecimento a 500 e $600^{\circ} \mathrm{C}$ por 1,3 e $12 \mathrm{~h}$, na microestrutura e na resistência à corrosão do AID UNS S31803. Os aços foram caracterizados por MEV, EDS, DRX, dureza, microdureza e análise térmica, e observou-se que os aços tratados termicamente por envelhecimento apresentaram fração volumétrica de ferrita menor que do aço solubilizado. E os aços envelhecidos a $500^{\circ} \mathrm{C}$ por $1 \mathrm{~h}$ apresentaram a fase alfa linha dispersa na ferrita e os aços envelhecidos a $600^{\circ} \mathrm{C}$ por $12 \mathrm{~h}$, apresentaram as fases alfa linha, sigma e chi. Nos ensaios reativação potenciodinâmico duplo ciclo em solução de $0.5 \mathrm{M} \mathrm{H} \mathrm{H}_{2} \mathrm{SO}_{4}$ e $0.01 \mathrm{M} \mathrm{KSNC}$, observou-se que não ocorreu a sensitização. E nos ensaios de polarização potenciodinâmica cíclica, em solução $3.5 \% \mathrm{NaCl}$, verificou-se que a precipitação da fase alfa linha não alterou a resistência à corrosão, porém a fase sigma reduziu a resistência à corrosão.

Palavras-chave: Aço inoxidável duplex; Corrosão; Transformação de fases; Envelhecimento. 


\begin{abstract}
Resumen
Los aceros inoxidables dúplex (AID) corresponden a una clase de acero en la que la microestructura está compuesta básicamente por las fases ferrita y austenita. Y debido al carácter metaestable de la ferrita, pueden ocurrir transformaciones en las fases asociadas durante los tratamientos térmicos como la línea alfa y sigma, lo que puede conducir a una disminución de la resistencia a la corrosión. Así, el objetivo de este trabajo fue evaluar la influencia de los tratamientos térmicos de solubilización a $1100^{\circ} \mathrm{C}$ durante $30 \mathrm{~min}$ y envejecimiento a 500 y $600^{\circ} \mathrm{C}$ durante 1,3 y 12h, sobre la microestructura y resistencia a la corrosión de AID UNS S31803. Los aceros se caracterizaron por SEM, EDS, DRX, dureza, micro dureza y análisis térmico, y se observó que los aceros tratados térmicamente por envejecimiento presentaban una fracción volumétrica de ferrita menor que el acero solubilizado. Y los aceros envejecidos a $500^{\circ} \mathrm{C}$ durante $1 \mathrm{~h}$ presentaron la fase de línea alfa dispersa en ferrita y los aceros envejecidos a $600{ }^{\circ}$ $\mathrm{C}$ durante $12 \mathrm{~h}$ presentaron las fases de línea alfa, sigma y chi. En los ensayos de reactivación potencio dinámica de doble ciclo en una solución de $\mathrm{H}_{2} \mathrm{SO}_{4} 0,5 \mathrm{M}$ y KSNC 0,01M, se observó que no se produjo sensibilización. Y en las pruebas de polarización potencio dinámica cíclica, en una solución de $\mathrm{NaCl}$ al 3,5\%, se encontró que la precipitación de la fase de línea alfa no cambiaba la resistencia a la corrosión, pero la fase sigma reducía la resistencia a la corrosión.
\end{abstract}

Palabras clave: Acero inoxidable dúplex; Corrosión; Transformación de fase; Envejecimiento.

\title{
1. Introduction
}

Duplex stainless steels (DSS) present low carbon content because of the process of decarburization by oxygen blowing associated to the argon used in its production, which, associated to a biphasic microstructure, composed of ferrite ( $\alpha$ ) and austenite $(\gamma)$, promote high corrosion resistance, good weldability, besides high mechanical resistance. Nevertheless, the typical microstructure can be modified by the thermal treatments of solubilization and aging (Örnek, Burke, Hashimoto, Lim \& Engelberg, 2017, Sicupira, Cardoso Junior, Bracarense, Frankel \& Lins, 2016).

The thermal treatment of solubilization aims at adjusting the volumetric fractions between the phases $\alpha$ and $\gamma$, by the growth of the austenite grains, and at solubilizing intermetallic phases present in steel, such as sigma $(\sigma)$, chi $(\chi)$ and alpha line ( $\alpha$ ’) (Örnek \& Engelberg, 2015, Sáenz et al., 2020, Zeng, Yang, Xu, Xin \& Li, 2019, Zhang et al., 2017). The thermal treatment of solubilization is usually performed between $1000-1200^{\circ} \mathrm{C}$, followed by cooling in water, to avoid the precipitation of undesirable intermetallic phases (Arturo, Hugo, Rafael, Egberto \& Antonio, 2015, Majid \& Shahi, 2020, Sáenz et al., 2020, Zeng et al., 2019). The thermal treatment of aging aims at promoting the precipitation of intermetallic phases such as $\alpha$, $\sigma$ and $\chi$, and it can be performed after the thermal treatment of solubilization, for the steel to present only the desired phases according to the application (Berecz, Fazakas, Mészáros \& Sajó, 2015, Chail \& Kangas, 2016, Cronemberger et al., 2014, Cronemberger, M. E. R., Nakamatsu, S., Rovere, C. A. D., Kuri, S. E. \& Mariano, N. A., 2015).

Phase $\alpha^{\prime}$ is a precipitate rich in chromium and it occurs inside $\alpha$, it presents a body-centered cubic (BCC) structure, coherent with the ferritic matrix, and since it has low energy of interface with the ferritic matrix, it presents high resistance to coalescence (Chen \& Limin, 2015, Cronemberger et al., 2015, Hilders, Zambrano \& Ochoa, 2018, Jinlong, Tongxiang, Lacerda, Cândido, \& Godefroid, 2015). The precipitation of phase $\alpha$ ' is associated to the diffusion of chromium and, therefore, it promotes the formation of regions poor in chromium around it. Thus, DSS becomes more susceptible to the localized corrosion, for being sensitive to active dissolution and contributing to the degradation of passive film stability (Hilders et al., 2018, Jinlong et al., 2015, Lacerda et al., 2015, Li, Lo, Kwok, Sun \& Lai, 2018, Mandal, 2016, Mohammed, Shrikrishna \& Sathiya, 2016, Verma \& Taiwade, 2017).

Furthermore, the formation of $\alpha^{\prime}$ causes a cross-stich displacement, leading to a decreased mobility of disagreements, leading to an increase in hardiness, in the yield point and mechanical resistance, besides reducing toughness and elongation (Appleton, 2019, Llorca-Isern, López-Jiménez, López-Luque, Biezma \& Roca, 2016, Mandal, 2016, Marques, Silva \& Santos, 2020, Mohammed et al., 2016, Paulraj \& Garg, 2015, Rezende et al. 2018, Rezende, Dainezi, Apolinario, Sousa \& Mariano, 2019, Silva et al., 2016, Rivolta, Gerosa \& Tavasci, 2018, Silva et al., 2016, Verma \& Taiwade, 2017).

Phase $\alpha^{\prime}$ can be formed by two mechanisms, nucleation and growth, and spinodal decomposition of ferrite, depending 
on the chemical composition of the ferrite phase and the temperature of the treatment. Both mechanisms occur to reduce the Gibbs free energy of the system and, consequently, promote a thermodynamically more stable state (Appleton, 2019, LlorcaIsern et al., 2016, Marques et al., 2020, Mohammed et al., 2016, Paulraj \& Garg, 2015, Rezende et al. 2018, Rivolta et al., 2018, Silva et al., 2016, Verma \& Taiwade, 2017).

The mechanism of nucleation and growth occurs when the chromium content in the ferrite phase is inferior to $23 \%$ (mass) and the thermal treatment of aging is performed above $500^{\circ} \mathrm{C}$. For this mechanism, the diffusion occurs with a greater reduction in the Gibbs free energy and phase $\alpha^{\prime}$ is more roughly formed than in the spinodal decomposition, because of the formation of coherent interfaces (Cavalcanti, Muterlle \& Reinke, 2019, Haupt, Silva, Falcade, Santos \& Reguly, 2019, Kisasoz, Gurel \& Karaaslan, 2016, Mehta, Jadhav, Shaikh, Kumar \& Kirwai, 2019, Nithin, Sekar \& Joseph, 2019, Ogawa \& Osuki, 2020, Powar, Gujar, Manthani, Pawar \& Singh, 2017, Valeriano, Correa, Mariano, Robin \& Machado, 2019).

The mechanism of spinodal decomposition of ferrite occurs when the chromium content is superior to $23 \%$ (in mass) and the thermal treatment of aging is performed at $280-475^{\circ} \mathrm{C}$ (Hilders et al., 2018, Jinlong et al., 2015, Lacerda et al., 2015, Li et al., 2018). The condition for spinodal decomposition to occur is that the alloy composition be the one in which the curve of free energy presents a negative curvature, in other words: $\partial^{2} G / \partial \chi^{2}<0$.

This condition is observed for systems at low temperatures and where mixing enthalpy is positive, in other words, $\Delta \mathrm{Hmix}>0$. This last factor occurs because of a characteristic of atoms of having more favorable ligations among equal species than different species. Thus, when chemical composition and temperature are located inside the chemical spinodal, phase $\alpha$ is unstable, there is no nucleation barrier, and decomposition occurs in diffusion of the "up-hill" type, nucleating phase $\alpha$ ', by spinodal decomposition.

Nonetheless, in case the composition is inside the miscibility GAP and outside the chemical spinodal, phase $\alpha$ is metastable; thus, there might occur the formation of phase $\alpha$, by nucleation and growth, and the diffusion is of the "down-hill" type.

Phase sigma derives from a reaction in the eutectoid, in which the ferrite phase is decomposed into sigma and secondary austenite $\left({ }^{\alpha} \rightarrow \sigma+\gamma_{2}\right)$ (Majid \& Shahi, 2020, Örnek \& Engelberg, 2015, Sáenz et al., 2020, Zeng et al., 2019). This reaction is started around the grains $\alpha / \gamma$ or $\alpha / \alpha$, and the consumption of the ferrite phase grows. Its precipitation occurs by the diffusion of the elements chromium, molybdenum and silicon, and with this, there is the formation of regions poor in these elements, leaving DSS with lower corrosion resistance, besides reducing ductility and toughness (Deng \& Zheng, 2019, Dille et al., 2017, Matias, Tavares, Pardal \& Ribeiro, 2017, Mehta et al., 2019, Nithin et al., 2019, Ogawa \& Osuki, 2020, Xiang, Liu, Silva et al., 2016).

Phase chi is thermodynamically unstable and is usually precipitated around the grains $\alpha / \gamma$ or $\alpha / \alpha$ (Örnek et al., 2017). Usually, phase chi is consumed by the phases sigma and austenite, and this tends to weaken and reduce the localized corrosion resistance of DSS (Alvarez-Armas \& Degallaix-Moreuil, 2009, Martins \& Hara, 2004, Morais \& Magnabosco, 2017, Silva et al., 2016, Santos \& Magnabosco, 2015, Warren et al., 2015).

Therefore, the aim of this work was to evaluate the influence of the thermal treatments of solubilization and aging on phase precipitation and electrochemical corrosion behavior, employing the techniques of cyclic potentiodynamic polarization and by the double cycle potentiodynamic reactivation (DL-EPR).

\section{Methodology}

The research methodology applied in this study is experimental/laboratory, relying on quantitative and qualitative approaches, as it is aimed at testing hypotheses in numerical and observed forms about the phase transformation resulting from 
the aging heat treatment (Ludke \& Andre, 2013, Koche, 2011, Pereira, Shitsuka, Parreira \& Shitsuka, 2018). Thus, the set of analyzes used to measure the influence of the phase transformation phenomenon occurring in duplex stainless steel about the modification of its corrosion resistance is described below.

The nominal chemical composition of the steel studied was determined by inductively coupled plasma atomic emission spectroscopy and is presented in Table 1.

Table 1: Nominal chemical composition of duplex stainless steel (wt.\%).

\begin{tabular}{cccccccc}
\hline $\mathbf{C r}$ & $\mathbf{N i}$ & $\mathbf{M o}$ & $\mathbf{M n}$ & $\mathbf{S i}$ & $\mathbf{N}$ & $\mathbf{C}$ & $\mathbf{F e}$ \\
\hline 23.0 & 5.5 & 3.15 & 1.97 & 0.45 & 0.17 & 0.015 & bal. \\
\hline
\end{tabular}

Source: Authors (2021).

The samples were solution-treated at $1100^{\circ} \mathrm{C}$ for $30 \mathrm{~min}$ and cooled in water. After that, aging treatments were performed at 500 and $600^{\circ} \mathrm{C}$ for 1,3 and $12 \mathrm{~h}$, followed by cooling in water.

The samples were analyzed by scanning electron microscopy (SEM) and the semi-quantitative microanalysis of the phases was obtained by energy-dispersive spectroscopy (EDS), after chemical attack with Behara $(2.02 \mathrm{M} \mathrm{HCl}$ and $0.045 \mathrm{M}$ $\mathrm{K}_{2} \mathrm{~S}_{2} \mathrm{O}_{5}$ ).

X-ray diffraction (XRD) analysis was performed with $\mathrm{Cu} \mathrm{K} \alpha$ radiation, in a range of $2 \theta$ from $40^{\circ}$ to $100^{\circ}$, with a step of $0.02^{\circ}$ for $2 \mathrm{~s} / \mathrm{step}$.

Thermal analysis was performed using differential scanning calorimetry (DSC) in the equipment Netzsch Júpiter STA $449 \mathrm{~F} 3$, the samples were submitted to heating from $30^{\circ} \mathrm{C}$ to $1200^{\circ} \mathrm{C}$, at a heating rate of $5^{\circ} \mathrm{C} / \mathrm{min}$, under an argon and nitrogen atmosphere.

The corrosion behavior was evaluated by the cyclic potentiodynamic polarization method using a potentiostat Metrohm model Autolab/PGSTART 302 connected to a typical electrochemical cell with a saturated calomel electrode (SCE) used as a reference electrode, a platinum plate employed as counter-electrode and the working electrode made from the steel studied. Electrochemical measurements were performed in triplicate for each condition. The electrolyte used was $3.5 \%$ sodium chloride solution at $25^{\circ} \mathrm{C}$. The potentiodynamic curves were measured at a potential scan rate of $1 \mathrm{mV} / \mathrm{s}$ in the range from $1.5 \mathrm{~V}$, with reversion of the direction when the anodic current density of $10^{-3} \mathrm{~A} / \mathrm{cm}^{2}$ was reached.

The corrosion tests by double cycle potentiodynamic reactivation (DL-EPR) were performed in the solutions $0.5 \mathrm{M}$ $\mathrm{H}_{2} \mathrm{SO}_{4}$ and $0.01 \mathrm{M} \mathrm{KSNC}$. The DL-EPR curves were obtained by scanning the potential from 0.5 to $0.3 \mathrm{~V}$, the scan was reversed and swept from positive to negative potentials at $-0.5 \mathrm{~V}$ at a constant rate of $2 \mathrm{mV} / \mathrm{s}$.

The corrosion tests were performed in the samples in which there was precipitation of the alpha line phase, to evaluate its effect in relation to the samples under the conditions as-received and solubilized.

The microhardness (HV) test was performed with a load of $0.1 \mathrm{kgf}$ and printing time of 15 seconds, and hardness (HRC) was also determined with a conical penetrator of $120^{\circ}$ and load of $150 \mathrm{kgf}$. Ferritoscopy assay was also performed for the DSS samples under the conditions studied.

\section{Results and Discussion}

The micrograph of the DSS UNS S31803 as received are shown in Figure 1a, and in the regions indicated by A and B, the EDS analyses were performed. The austenite phase was observed in the form of elongated islands, and in alternate regions of refined and acicular structures, dispersed in the ferritic matrix. Figure 1b shows a micrograph of UNS S31803 solution- 
treated at the temperature of $1100^{\circ} \mathrm{C}$ for 30 min and cooled with water.

Figure 1: Micrographs obtained by SEM of duplex stainless steel DSS UNS S31803. (a) As-received; (b) Solution-treated at $1100^{\circ} \mathrm{C}$ for $30 \mathrm{~min}$ and cooled in water.

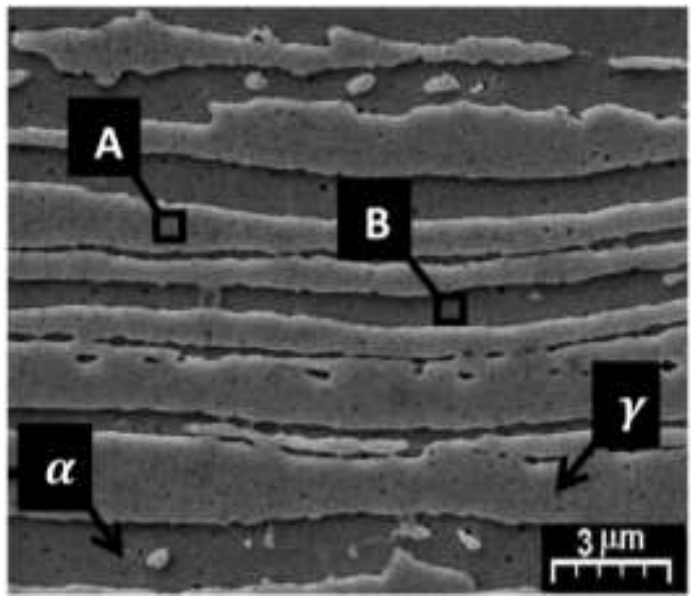

(a)

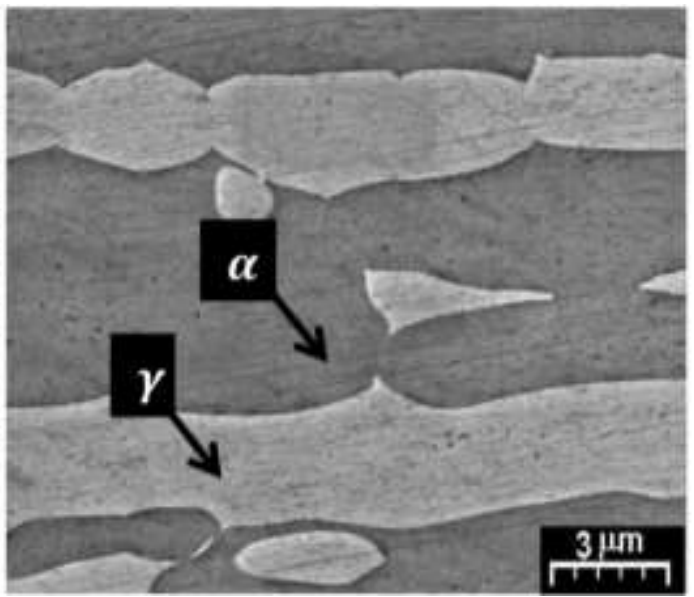

(b)

Source: Authors (2021).

The austenite is observed in the form of lamella islands, distributed in the ferritic matrix. It is noted that the solutiontreated resulted in a microstructure with homogeneous distribution between the phases and there was the growth of austenite, because of the diffusion of gammagenic alloy elements such as Ni, C and Mn.

The duplex microstructure is formed during cooling, and firstly, austenite presents the Widmanstätten morphology inside and around the grains of ferrite; subsequently, it undergoes transformation in state by the diffusion of alloy elements and displacement of interfaces, imposing an orientation relationship of the type Kurdjumov-Sachs (K-S) or Nishiyama-Wasserman $(\mathrm{N}-\mathrm{W})$ between the new austenite and the precursor ferrite, generating semi-coherent interfaces (Alvarez-Armas \& DegallaixMoreuil, 2009).

Austenite stringers around the ferrite grains maintain this type of orientation relationship with one of the ferrite grains, whereas the other interface has an incoherent limit. The result is a distribution of austenite monocrystals in the form of plates oriented in space almost at random within a ferrite matrix (Alvarez-Armas \& Degallaix-Moreuil, 2009).

Figures $2 \mathrm{a}, 2 \mathrm{~b}$ and $2 \mathrm{c}$ show DSS UNS S31803 micrographs, under the condition aged at $500^{\circ} \mathrm{C}$ for 1,3 and $12 \mathrm{~h}$, respectively. It is observed that the thermal treatment of aging performed at $500^{\circ} \mathrm{C}$ for $1 \mathrm{~h}$ (Figure $2 \mathrm{a}$ ) was able to precipitate phase $\alpha^{\prime}$, inside the ferrite, by the mechanism of nucleation and growth. The morphology of phase $\alpha$ ' is a consequence of the differences between the thermal expansion of ferrite and of $\alpha^{\prime}$, besides the proximity between the network parameters between the matrix and the precipitate which led to the formation of coherent interfaces and a spherical appearance with diameters of approximately $100 \mathrm{~nm}$. Furthermore, it is noted by Figures $2 \mathrm{~b}$ and $2 \mathrm{c}$ that there was a growth of the austenite grains because of the diffusion of the alloy elements, analogously to the observed after the solution-treated, Figure $1 \mathrm{~b}$. 
Figure 2: Micrographs of DSS UNS S31803, under the conditions aged at $500^{\circ} \mathrm{C}$. (a) Aging time of $1 \mathrm{~h}$; (b) Aging time of 3h; (c) Aging time of $12 \mathrm{~h}$.

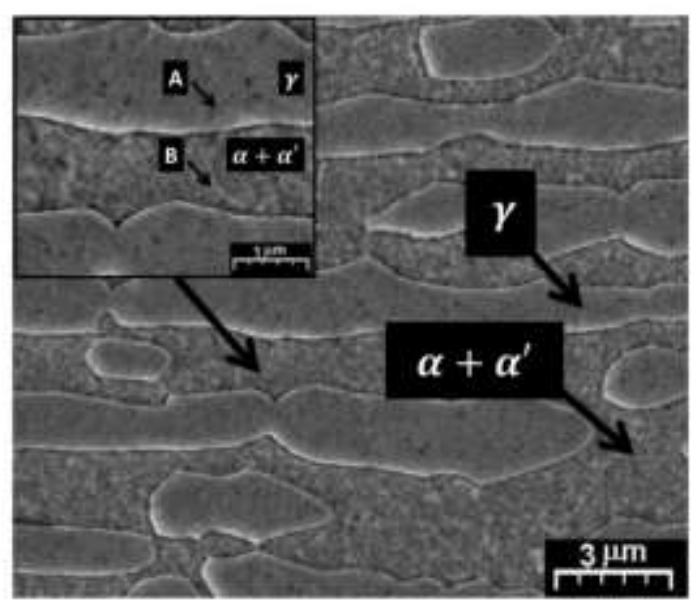

(a)

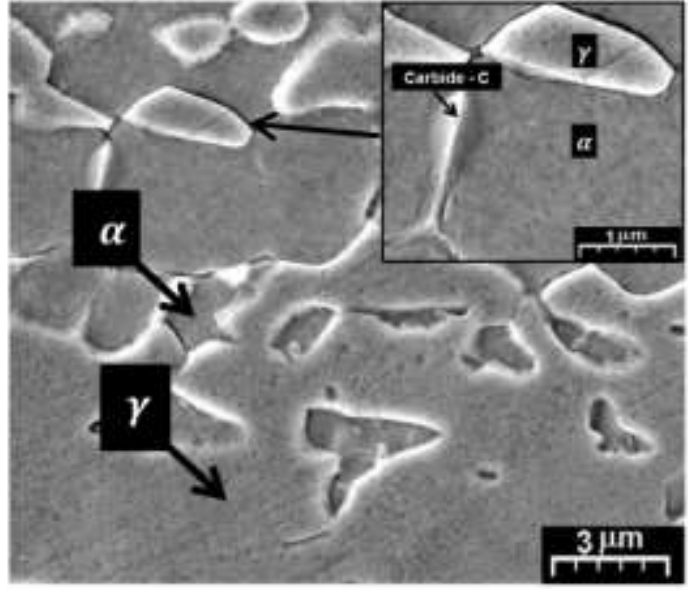

(b)

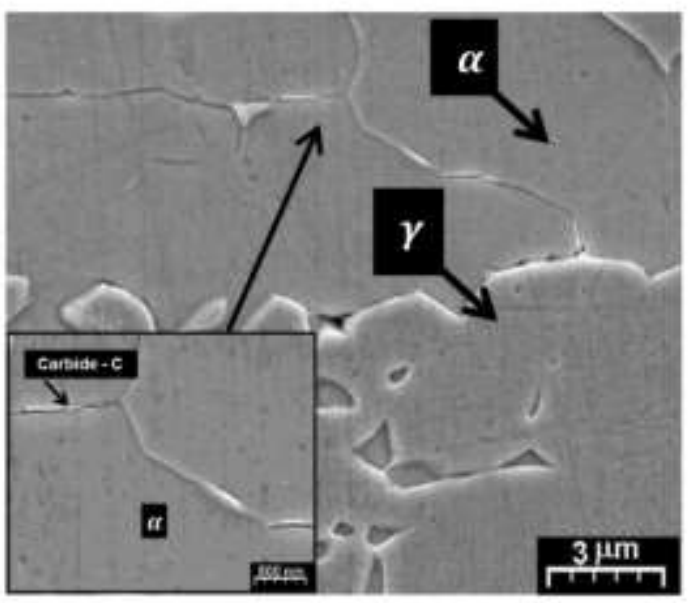

(c)

Source: Authors (2021).

The micrographs obtained by scanning electron microscopy for UNS S31803 aged at $600^{\circ} \mathrm{C}$ for 1,3 and $12 \mathrm{~h}$ are shown in Figure 3. An alteration in austenite morphology was observed in the three times of aging treatment, changing from elongated islands to a massive structure, deriving from the growth of the austenite grains followed by their union, promoting a heterogeneous microstructure. The treatment of aging at $600^{\circ} \mathrm{C}$ for $12 \mathrm{~h}$ promoted the precipitation of phase $\alpha^{\prime}$, by the method of nucleation and growth, with morphology similar to the treatment of aging at $500^{\circ} \mathrm{C}$ for $1 \mathrm{~h}$ (Figure 2a). 
Figure 3: Micrographs of DSS UNS S31803, under the condition aged at $600^{\circ} \mathrm{C}$. (a) Aging time of $1 \mathrm{~h}$; (b) Aging time of 3h; (c) Aging time of $12 \mathrm{~h}$.

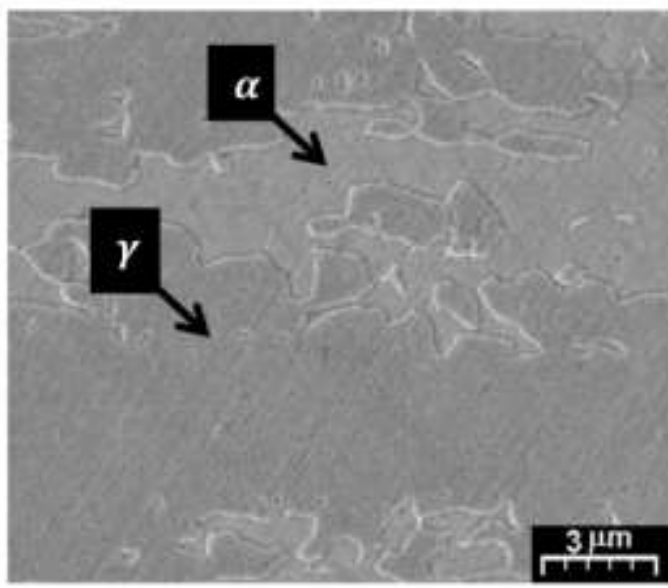

(a)

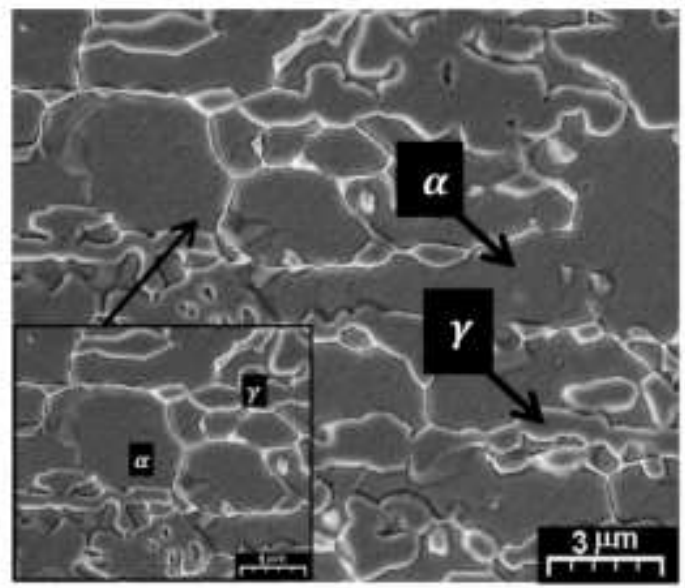

(b)

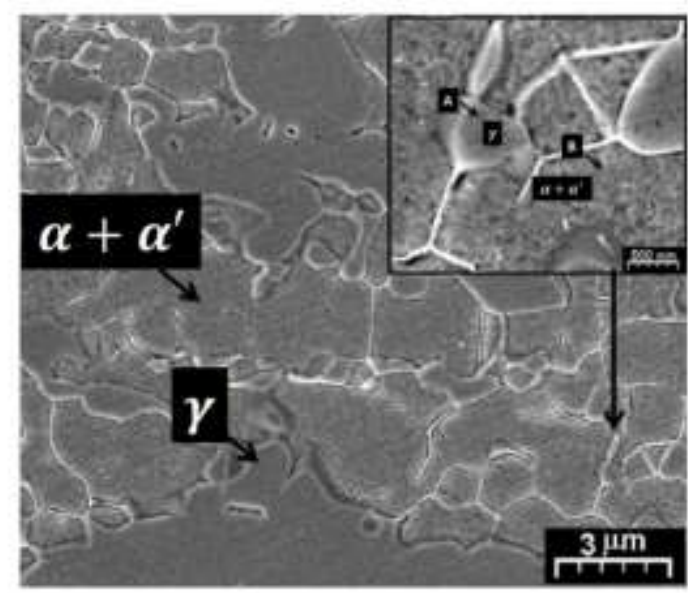

(c)

Source: Authors (2021).

The results of the semiquantitative microanalyses by energy-dispersive spectroscopy (EDS) in the regions A (phase $\gamma$ ) and $\mathrm{B}$ (phase $\alpha$ ), under the conditions as-received, solution-treated, aged at $500^{\circ} \mathrm{C}$ for 1 and $600^{\circ} \mathrm{C}$ for $12 \mathrm{~h}$ are shown in Table 2. 
Table 2: Semiquantitative microanalysis by EDS under the conditions as-received, solution-treated and aging at $500^{\circ} \mathrm{C}$ for $1 \mathrm{~h}$ and $600^{\circ} \mathrm{C}$ for $12 \mathrm{~h}$ (in $\%$ mass).

\begin{tabular}{cccccc}
\hline DSS UNS S31803 & Phases & Fe & Cr & Ni & Mo \\
\hline As-received & $\alpha$ & 62.95 & 24.43 & 5.01 & 5.23 \\
& $\gamma$ & 65.74 & 22.28 & 7.07 & 2.98 \\
\hline \multirow{2}{*}{ Solution-treated at $1100^{\circ} \mathrm{C}$} & $\alpha$ & 64.87 & 24.23 & 4.41 & 4.30 \\
& $\gamma$ & 66.13 & 21.49 & 6.86 & 2.50 \\
\hline \multirow{2}{*}{ Aged at $500^{\circ} \mathrm{C}$ for $1 \mathrm{~h}$} & $\alpha+\alpha$ & 61.04 & 23.89 & 4.82 & 6.71 \\
& $\gamma$ & 63.43 & 20.57 & 7.31 & 4.06 \\
\hline \multirow{2}{*}{ Aged at $600^{\circ} \mathrm{C}$ for $12 \mathrm{~h}$} & $\alpha+\alpha$ & 61.69 & 24.15 & 4.78 & 6.55 \\
\hline
\end{tabular}

Source: Authors (2021).

It is observed that the alloy elements chromium and molybdenum are majoritarian in the ferrite phase, because of the ferritizing character of these elements, whereas the alloy element nickel is majoritarian in austenite, given the austenitizing character. It was also observed that there were no significant variations in the contents of chromium, molybdenum and nickel under the studied conditions, even with the precipitation of phase $\alpha^{\prime}$ inside ferrite.

Figure 4 presents the X-ray diffraction spectra of DSS UNS S31803 under the studied conditions. It was observed that the solution-treated the intermetallic phases $\sigma$ and $\chi$ present under the condition as-received. Furthermore, the precipitation of phase $\sigma$ was observed, in the thermal treatments of aging performed at $500^{\circ} \mathrm{C}$ for $1 \mathrm{~h}$ and at $600^{\circ} \mathrm{C}$ at the times of 1,3 and $12 \mathrm{~h}$, and the precipitation of phase $\chi$, aging at $600^{\circ} \mathrm{C}$ for 1 hour.

Figure 4: X-ray diffraction spectra of the duplex stainless steels under the conditions. (a) Aged at $500^{\circ} \mathrm{C}$; (b) Aged at $600^{\circ} \mathrm{C}$.

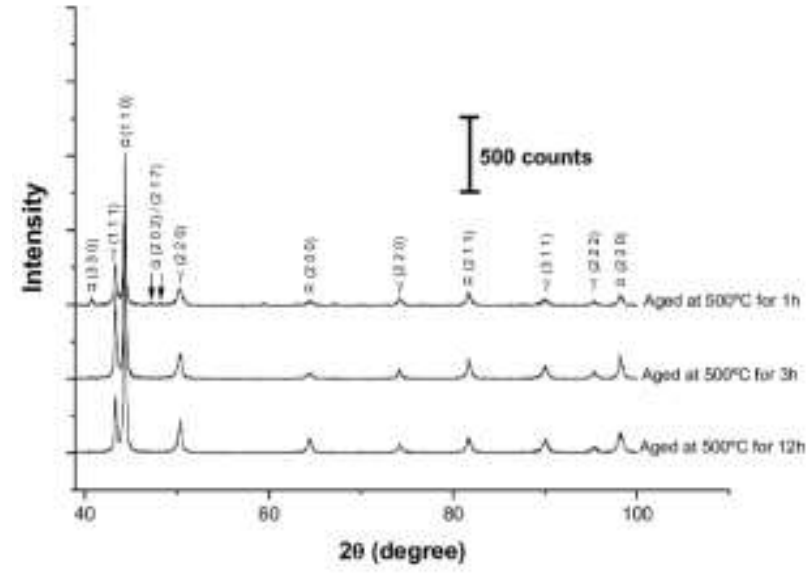

(a)

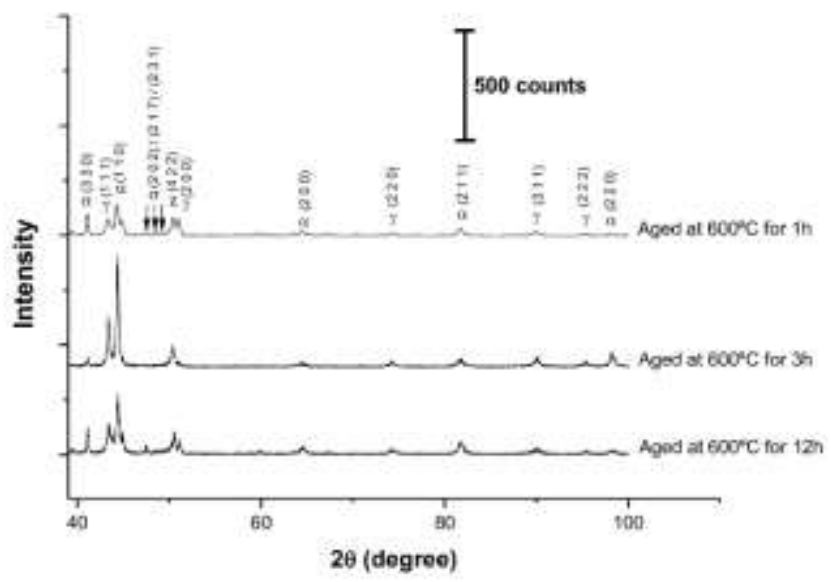

(b)

Source: Authors (2021).

Table 3 shows the volumetric fractions of the ferrite phase, measured using a ferritoscope. A decrease in the volumetric fraction of ferrite was observed in the thermal treatments of aging, in relation to the conditions as-received and solubilized, deriving from both the growth of the austenite grains and the precipitation of phases $\sigma$ and $\chi$, as shown in Figure 4 . Phase sigma derives from a reaction in eutectoid, formed by the decomposition of ferrite, leading to the reduction in the 
volumetric fraction of ferrite (Alvarez-Armas \& Degallaix-Moreuil, 2009).

Table 3: Volumetric fraction of the ferrite phase in DSS UNS S31803.

\begin{tabular}{cc}
\hline DSS UNS S31803 & $\begin{array}{c}\text { Volumetric fraction of the } \\
\text { ferrite phase }(\%)\end{array}$ \\
\hline As-received & $41.97 \pm 0.96$ \\
Solution-treated at $1100^{\circ} \mathrm{C}$ & $41.39 \pm 0.72$ \\
Aged at $500^{\circ} \mathrm{C}$ for $1 \mathrm{~h}$ & $37.85 \pm 0.58$ \\
Aged at $500^{\circ} \mathrm{C}$ for $3 \mathrm{~h}$ & $37.18 \pm 0.72$ \\
Aged at $500^{\circ} \mathrm{C}$ for $12 \mathrm{~h}$ & $30.77 \pm 0.98$ \\
Aged at $600^{\circ} \mathrm{C}$ for $1 \mathrm{~h}$ & $39.88 \pm 0.55$ \\
Aged at $600^{\circ} \mathrm{C}$ for $3 \mathrm{~h}$ & $34.62 \pm 0.52$ \\
Aged at $600^{\circ} \mathrm{C}$ for $12 \mathrm{~h}$ & $36.04 \pm 0.72$ \\
\hline
\end{tabular}

Source: Authors (2021).

Table 4 shows the hardness values obtained for DSS under the studied conditions, and a decrease in hardness was observed after the solution-treat, deriving from the dissolution of the intermetallic phases $\sigma$ and $\gamma$, present in the as-received steel. In the steel aged at $500^{\circ} \mathrm{C}$ for $1 \mathrm{~h}$, there was the precipitation of phases $\alpha^{\prime}$ and $\sigma$, which present weakening and hardening characteristics, promoting higher hardness, in relation to the aging times of 3 and $12 \mathrm{~h}$. The treatment of aging at $500^{\circ} \mathrm{C}$ for $1 \mathrm{~h}$ (Figure 2a) and $600^{\circ} \mathrm{C}$ for $12 \mathrm{~h}$ (Figure 3c) promoted the precipitation of phase $\alpha^{\prime}$, which presents hardening characteristics, which led to an increase in hardness in relation to the other times.

Table 4: Results of DSS UNS S31803 hardness (HRC).

\begin{tabular}{cc}
\hline DSS UNS S31803 & Hardness (HRC) \\
\hline As-received & $24 \pm 1$ \\
Solution-treated at $1100^{\circ} \mathrm{C}$ & $15 \pm 2$ \\
Aged at $500^{\circ} \mathrm{C}$ for $1 \mathrm{~h}$ & $23 \pm 1$ \\
Aged at $500^{\circ} \mathrm{C}$ for $3 \mathrm{~h}$ & $21 \pm 1$ \\
Aged at $500^{\circ} \mathrm{C}$ for $12 \mathrm{~h}$ & $22 \pm 1$ \\
Aged at $600^{\circ} \mathrm{C}$ for $1 \mathrm{~h}$ & $22 \pm 1$ \\
Aged at $600^{\circ} \mathrm{C}$ for $3 \mathrm{~h}$ & $22 \pm 1$ \\
Aged at $600^{\circ} \mathrm{C}$ for $12 \mathrm{~h}$ & $23 \pm 1$ \\
\hline
\end{tabular}

Source: Authors (2021).

Table 5 shows the microhardness values for the phases ferrite and austenite under the studied conditions. It was observed that after the solution-treated, there was no significant variation in the microhardness values. The ferrite phase presented the highest microhardness values under the conditions of aging at $500^{\circ} \mathrm{C}$ for $1 \mathrm{~h}(276.8 \pm 4.2 \mathrm{HV} 10)$ and $600^{\circ} \mathrm{C}$ for $12 \mathrm{~h}(278.9 \pm 2.7 \mathrm{HV} 10)$, because of the precipitation of phase $\alpha$ ' inside ferrite. It was observed that there was no significant variation in the microhardness values of the austenite phase, suggesting that the precipitation of phase $\mathrm{G}$ did not occur inside austenite. 
Table 5: Results of the microhardness (HV10) of the phases present in DSS UNS S31803.

\begin{tabular}{|c|c|c|}
\hline DSS UNS S31803 & Phase & Microhardness (HV10) \\
\hline \multirow{2}{*}{ As-received } & $\alpha$ & $248.6 \pm 6.9$ \\
\hline & $y$ & $268.6 \pm 4.3$ \\
\hline \multirow{2}{*}{ Solution-treated at $1100^{\circ} \mathrm{C}$} & $\alpha$ & $254.4 \pm 3.9$ \\
\hline & $y$ & $270.8 \pm 4.8$ \\
\hline \multirow{2}{*}{ Aged at $500^{\circ} \mathrm{C}$ for $1 \mathrm{~h}$} & $\alpha$ & $276.8 \pm 4.2$ \\
\hline & $\gamma$ & $271.1 \pm 3.1$ \\
\hline \multirow{2}{*}{ Aged at $500^{\circ} \mathrm{C}$ for $3 \mathrm{~h}$} & $\alpha$ & $255.9 \pm 3.5$ \\
\hline & $y$ & $272.1 \pm 3.7$ \\
\hline \multirow{2}{*}{ Aged at $500^{\circ} \mathrm{C}$ for $12 \mathrm{~h}$} & $\alpha$ & $264.7 \pm 3.9$ \\
\hline & $\gamma$ & $272.6 \pm 2.7$ \\
\hline \multirow{2}{*}{ Aged at $600^{\circ} \mathrm{C}$ for $1 \mathrm{~h}$} & $\alpha$ & $253.1 \pm 2.4$ \\
\hline & $\gamma$ & $271.8 \pm 1.7$ \\
\hline \multirow{2}{*}{ Aged at $600^{\circ} \mathrm{C}$ for $3 \mathrm{~h}$} & $\alpha$ & $255.1 \pm 3.5$ \\
\hline & $y$ & $271.9 \pm 1.6$ \\
\hline \multirow{2}{*}{ Aged at $600^{\circ} \mathrm{C}$ for $12 \mathrm{~h}$} & $\alpha$ & $278.9 \pm 2.7$ \\
\hline & $\gamma$ & $272.2 \pm 2.1$ \\
\hline
\end{tabular}

Source: Authors (2021)

Figure 5 presents the thermograms of steel DSS UNS S31803, obtained by differential scanning calorimetry (DSC), using nitrogen and argon atmospheres. The presence of an endothermic peak at $428.9^{\circ} \mathrm{C}$ and $520.4^{\circ} \mathrm{C}$ was observed in the argon and nitrogen atmospheres, respectively, suggesting the transformation of ferrite into $\alpha^{\prime}$, because of the decrease in chromium in the ferritic matrix, promoting an increase in ferromagnetic/paramagnetic transition temperature of ferrite. The exothermic peaks at $842.2^{\circ} \mathrm{C}$ and $860.6^{\circ} \mathrm{C}$, in the argon and nitrogen atmospheres, respectively, derives from the consumption of ferrite by paramagnetic phases, such as austenite and $\sigma$.

Figure 5: DSC thermogram for DSS UNS S31803 in argon and nitrogen atmospheres.

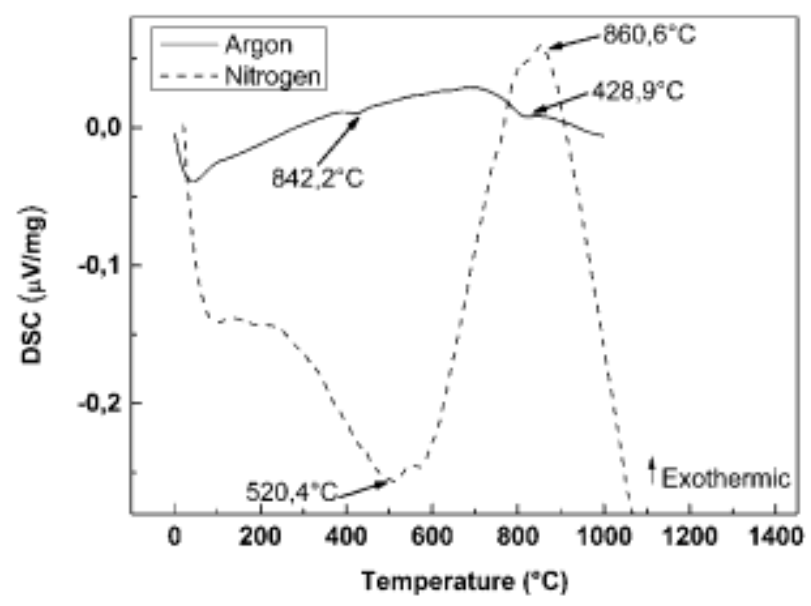

Source: Authors (2021). 
Assays of double cycle potentiodynamic reactivation (DL-EPR) and cyclic potentiodynamic polarization (CPP) were performed in a solution of $0.5 \mathrm{M} \mathrm{H} 2 \mathrm{SO} 4$ and $0.01 \mathrm{M} \mathrm{KSN}$, in the samples in which there was precipitation of phase $\alpha^{\prime}$ (aged at $500^{\circ} \mathrm{C}$ for $1 \mathrm{~h}$ and $600^{\circ} \mathrm{C}$ for $12 \mathrm{~h}$ ) and under the conditions as-received and solubilized, as shown in Figure 6.

Figure 6: Corrosion assay of DSS UNS S31803 in a solution of 0.5M H2SO4 and 0.01M KSNC. (a) Open circuit potential; (b) Double cycle potentiodynamic reactivation.

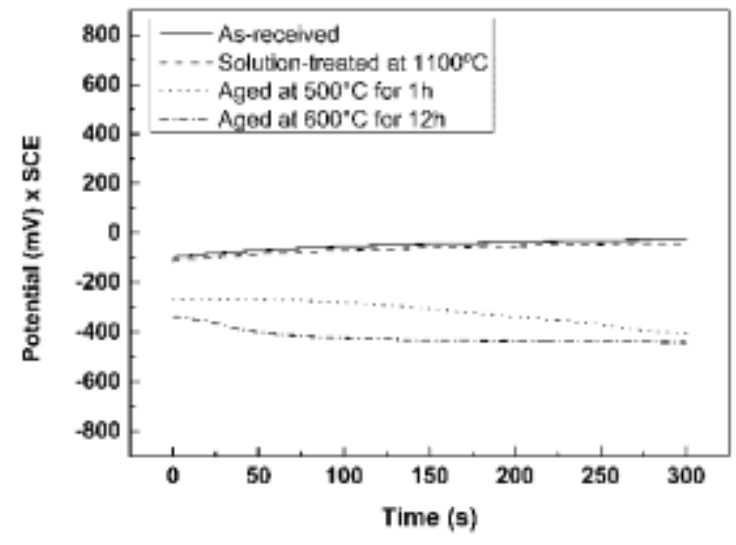

(a)

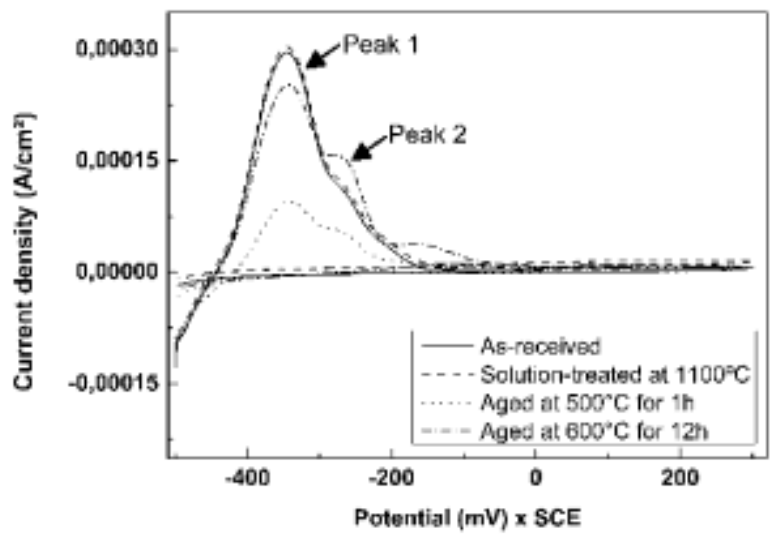

(b)

Source: Authors (2021).

The values of corrosion potentials (Ecorr) and degree of sensitization are presented in Table 6. It was observed that under the conditions as-received and solubilized, the values of the potentials increased with time, deriving from the formation of a stable passive layer that adheres to the steel surface. Nevertheless, under the conditions of aging at $500^{\circ} \mathrm{C}$ for $1 \mathrm{~h}$ and $600^{\circ} \mathrm{C}$ for $12 \mathrm{~h}$, the values of the potentials decreased over time, followed by a stabilization at the times of 250 seconds and 50 seconds, respectively, evidencing a generalized corrosion followed by the formation of a passive layer.

Table 6: Open circuit corrosion potential and degree of sensitization by double cycle potentiodynamic reactivation, of DSS UNS S31803 in solution of 0.5M H2SO4 and 0.01M KSNC.

\begin{tabular}{ccc}
\hline DSS UNS S31803 & Ecorr $(\mathbf{m V})$ & Degree of sensitization \\
\hline As-received & $-40 \pm 2$ & $0.0142 \pm 0.0008$ \\
Solution-treated at $1100^{\circ} \mathrm{C}$ & $-44 \pm 4$ & $0.0164 \pm 0.0004$ \\
Aged at $500^{\circ} \mathrm{C}$ for $1 \mathrm{~h}$ & $-402 \pm 7$ & $0.0025 \pm 0.0001$ \\
Aged at $600^{\circ} \mathrm{C}$ for $12 \mathrm{~h}$ & $-440 \pm 3$ & $0.0167 \pm 0.0007$ \\
\hline
\end{tabular}

Source: Authors (2021).

It was observed that the degree of sensitization was maintained below 0.5 , for all conditions, indicating that no sensitization occurred (Chail \& Kangas, 2016). This fact evidences that the passive layer was not disrupted and, therefore, the thermal treatments of aging and solubilization did not alter the resistance to intergranular corrosion of steel. Thus, the presence of phases $\alpha^{\prime}, \sigma$ and $\chi$ did not have significant effect on the degree of sensitization, because of the low precipitation of these deleterious phases, which promoted regions poor in chromium and molybdenum. Additionally, in Figure 6b, two peaks are observed in the activation current, the more noble potential corresponding to the austenite phase, and the less noble corresponding to the ferrite phase. 
Figures $7 \mathrm{a}$ and $7 \mathrm{~b}$ show the curves of open circuit potential (OCP) and of cyclic potentiodynamic polarization, respectively, in a 3.5\% sodium chloride solution, of steel DSS UNS S31803 under the condition as-received, solubilized, aged at $500^{\circ} \mathrm{C}$ for $1 \mathrm{~h}$ and $600^{\circ} \mathrm{C}$ for $12 \mathrm{~h}$.

Figure 7: Corrosion assay of DSS UNS S31803 in a 3.5\% sodium chloride solution. (a) Potential in open circuit; (b) Cyclic potentiodynamic polarization.

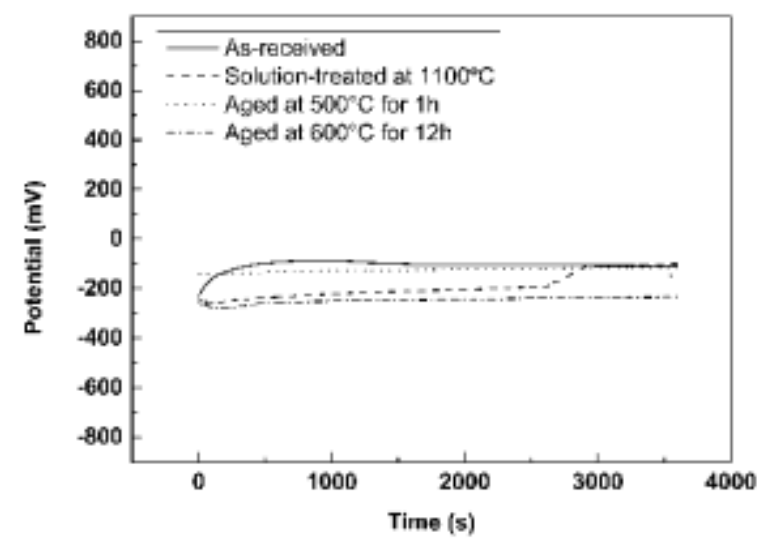

(a)

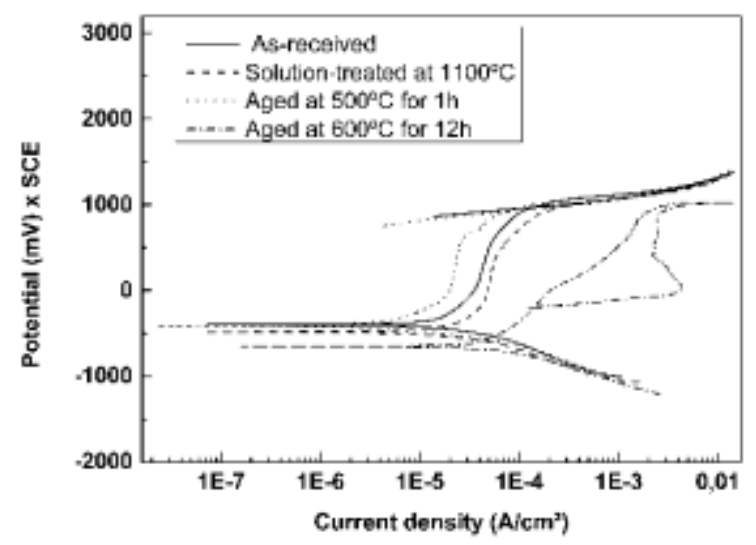

(b)

Source: Authors (2021).

From Figure 7a, the values of the corrosion potentials (Ecorr) were obtained, as shown in Table 7. It was observed that under the studied conditions, the values of the potentials increased over time, characterizing the formulation of a passive, stable and adherent layer on the surface of the steel.

Table 7: Open circuit corrosion potential of DSS UNS S31803 in a 3.5\% sodium chloride solution.

\begin{tabular}{cc}
\hline DSS UNS S31803 & Ecorr $(\mathbf{m V})$ \\
\hline As-received & $-114 \pm 7$ \\
Solution-treated at $1100^{\circ} \mathrm{C}$ & $-107 \pm 4$ \\
Aged at $500^{\circ} \mathrm{C}$ for $1 \mathrm{~h}$ & $-142 \pm 6$ \\
Aged at $600^{\circ} \mathrm{C}$ for $12 \mathrm{~h}$ & $-232 \pm 4$ \\
\hline
\end{tabular}

Source: Authors (2021).

From the polarization curves, Figure 7b, the electrochemical parameters were obtained, by the Tafel's extrapolation method, as shown in Table 8. 
Table 8: Electrochemical parameters obtained by cyclic potentiodynamic polarization, of DSS UNS S31803 in $3.5 \%$ sodium chloride solution.

\begin{tabular}{ccccc}
\hline DSS UNS S31803 & Ecorr $(\mathbf{m V})$ & Epit $(\mathbf{m V})$ & Eprot $(\mathbf{m V})$ & Ipass $\left(\mathbf{A} / \mathbf{c m}^{2}\right)$ \\
\hline As-received & $-400 \pm 8$ & $1056 \pm 3$ & $978 \pm 9$ & $(40.9 \pm 1.4) \times 10^{-6}$ \\
Solution-treated at $1100^{\circ} \mathrm{C}$ & $-440 \pm 6$ & $1037 \pm 7$ & $1008 \pm 3$ & $(46.9 \pm 2.2) \times 10^{-6}$ \\
Aged at $500^{\circ} \mathrm{C}$ for $1 \mathrm{~h}$ & $-414 \pm 1$ & $1038 \pm 1$ & $918 \pm 2$ & $(23.5 \pm 0.1) \times 10^{-6}$ \\
Aged at $600^{\circ} \mathrm{C}$ for $12 \mathrm{~h}$ & $-604 \pm 2$ & $967 \pm 8$ & $-148 \pm 12$ & $(11.3 \pm 0.1) \times 10^{-5}$ \\
\hline
\end{tabular}

Source: Authors (2021).

The values of corrosion potential obtained by open circuit were higher than those obtained by the cyclic potentiodynamic polarization curves, Tables 7 and 8 , respectively, because the partial removal of the passive layer in the polarization scan started in more negative potentials than the corrosion potential.

The polarization curves show the presence of two passive regions in all conditions tested. This occurred because of the difference in chromium and molybdenum contents between the ferrite and austenite phases, elements that passivate steel. Thus, the ferrite phase that presents higher contents of these elements passivates before the austenite phase.

The values of the electrochemical parameters: corrosion potential (Ecorr), pitting potential (Epit), protection potential (Eprot), corrosion current density (Icorr) and passivation current density (Ipass), under the conditions as-received, solutiontreated and aged at $500^{\circ} \mathrm{C}$ for $1 \mathrm{~h}$ did not present significant variations, indicating that the precipitation of phase $\alpha^{\prime}$, present in these conditions, did not affect steel corrosion properties.

Nevertheless, in the treatment of aging at $600^{\circ} \mathrm{C}$ for $12 \mathrm{~h}$, a reduction in the values of corrosion, pitting and protection potential was observed, because of the precipitation of phase sigma $(\sigma)$ and promoting the formation of regions poor in chromium, and consequently, reducing corrosion resistance. Furthermore, in this condition, higher passivation current density was observed, indicating that the passive layer was formed more slowly than in the other conditions.

Figures 8a and 8b show the micrographs obtained by SEM of DSS UNS S31803, aged at $500^{\circ} \mathrm{C}$ for $1 \mathrm{~h}$ and aged at $600^{\circ} \mathrm{C}$ for $12 \mathrm{~h}$, respectively, after the assays of corrosion by polarization, in a $3.5 \%$ sodium chloride solution. In the two conditions, the localized corrosion by pits was observed, being more intense under the condition aged at $600^{\circ} \mathrm{C}$ for $12 \mathrm{~h}$. The pits were classified as crystallographic (Pit-C), hemispherical (Pit-H) and irregular (Pit-I) and it is noted that pit nucleation occurred preferentially around grain $\alpha / \alpha$ and $\alpha / \gamma$ and inside the austenite grains, characterizing the selective corrosion. 
Figure 8: Micrographs obtained by SEM of DSS UNS S31803, after polarization assays, in a 3.5\% sodium chloride solution. (a) Aged at $500^{\circ} \mathrm{C}$ for $1 \mathrm{~h}$; (b) Aged at $600^{\circ} \mathrm{C}$ for $12 \mathrm{~h}$.

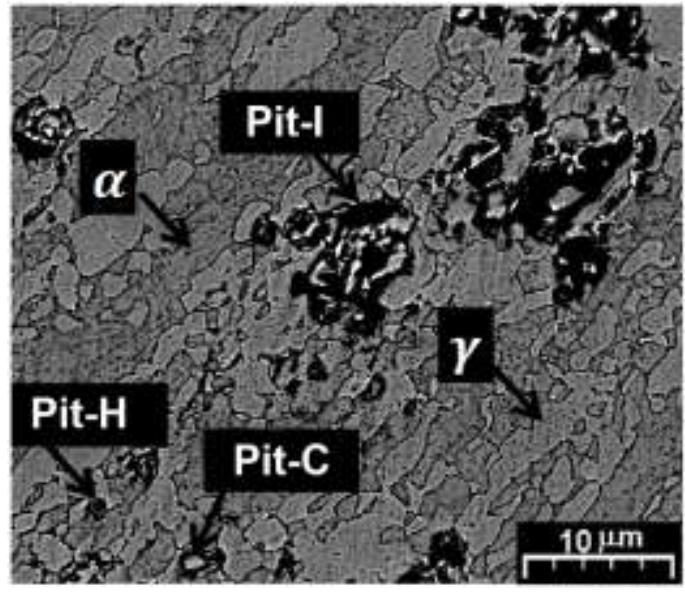

(a)

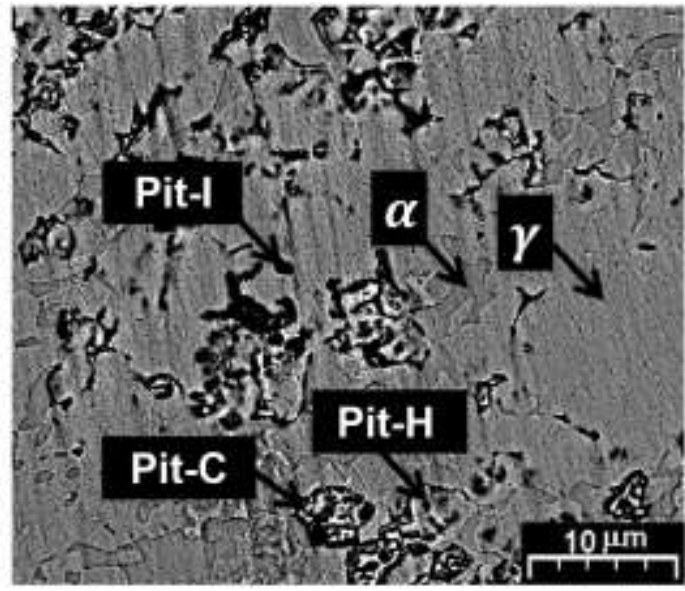

(b)

Source: Authors (2021).

Table 9 shows the pitting resistance equivalent number (PREN) of the ferrite and austenite phases, calculated from the chemical composition of the main alloy elements obtained by EDS (Table 2).

Table 9: Pitting resistance equivalent number (PREN) of the phases.

\begin{tabular}{ccc}
\hline DSS UNS S31803 & Phase & PREN \\
\hline As-received & $\alpha$ & 44 \\
Solution-treated at $1100^{\circ} \mathrm{C}$ & $\gamma$ & 35 \\
\hline \multirow{2}{*}{ Aged at $500^{\circ} \mathrm{C}$ for $1 \mathrm{~h}$} & $\alpha$ & 41 \\
& $\gamma$ & 32 \\
\hline \multirow{2}{*}{ Aged at $600^{\circ} \mathrm{C}$ for $12 \mathrm{~h}$} & $\alpha$ & 49 \\
& $\gamma$ & 37 \\
\hline
\end{tabular}

Source: Authors (2021).

It can be observed that a preferential selective corrosion of one of the phases may occur due to the significant difference of the PREN values between the phases. This difference is caused by the non-homogeneous distribution of the passivating elements; consequently, the passive layer can present a different composition between the phases, increasing the probability of occurring defects.

In Figure 8 , it is noted that the pits are nucleated around the grains and they grow in ferrite, even with this phase presenting a higher PREN value than austenite. This derives from the fact that the alloy elements $\mathrm{Cr}$ and Mo, besides passivators, are stabilizers in the ferrite phase, whereas in the austenite phase they act only as passivators. Therefore, for a corrosion resistance by pits similar to the austenite phase, the ferrite phase should contain higher contents of the elements $\mathrm{Cr}$ and Mo. 


\section{Conclusion}

The steel in the condition as-received presented a ferritic matrix with elongated austenite islands and the presence of phases $\sigma$ and $\chi$. The thermal treatment of solution promoted higher homogenization of the phases and growth of the austenite grains, besides promoting the dissolution of the intermetallic phases $\sigma$ and $\chi$.

The thermal treatment of aging performed at $500^{\circ} \mathrm{C}$ for $1 \mathrm{~h}$ promoted the precipitation of phase $\alpha^{\prime}$ dispersed in the ferritic matrix, whereas the aging performed at $600^{\circ} \mathrm{C}$ for $12 \mathrm{~h}$, besides the precipitation of phase $\alpha^{\prime}$, promoted the precipitation of phases $\sigma$ and $\chi$.

Additionally, the thermal treatments of aging reduced the volumetric fraction of the ferrite phase and/or promoted the precipitation of phases $\alpha^{\prime}$ and $\sigma$, increasing steel hardness.

The ferrite phase of the steels thermally treated by aging at $500^{\circ} \mathrm{C}$ for $1 \mathrm{~h}$ and $600^{\circ} \mathrm{C}$ for $12 \mathrm{~h}$ presented higher values of microhardness because of $\alpha$ ' precipitation. The austenite phase did not undergo significant variation in microhardness, indicating that phase $\mathrm{G}$ did not precipitate inside it.

By thermal analysis, the ferromagnetic-paramagnetic transformation of ferrite was observed at 428.9 and $520.4^{\circ} \mathrm{C}$, besides ferrite consumption by paramagnetic phases at 842.2 and $860.6^{\circ} \mathrm{C}$.

In the tests of double cycle potentiodynamic reactivation, it was observed that the steel did not suffer sensitization under the studied conditions. The open circuit potential assays revealed the formation of a passive and stable film, adherent to the steel surface. By the tests of cyclic potentiodynamic polarization, it was observed that the precipitation of phase $\alpha$ ' did not affect corrosion resistance; nevertheless, phase $\sigma$ reduced corrosion resistance.

In the steels aged at $500^{\circ} \mathrm{C}$ for $1 \mathrm{~h}$ and $600^{\circ} \mathrm{C}$ for $12 \mathrm{~h}$, the pits were nucleated around the grains and in the ferrite phase. The ferrite phase presented higher PREN values in relation to austenite, for presenting higher contents of Cr and Mo, which are passivating and alphagenic elements.

In addition, it is important to mention that future studies can be developed in terms of investigation of stress corrosion crack on the conditions evaluated, this topic is little explored in duplex stainless steels. It is also suggested an investigation of reactions resulting from corrosion by electrochemical impedance tests.

\section{Acknowledgments}

The authors thank Brazilian research funding agencies Fundação de Amparo à Pesquisa do Estado de Minas Gerais (FAPEMIG), Fundação de Amparo à Pesquisa do Estado de São Paulo (FAPESP), Conselho Nacional de Desenvolvimento Científico e Tecnológico $(\mathrm{CNPq})$, Financiadora de Estudos e Projetos (FINEP) and Coordenação de Aperfeiçoamento de Pessoal de Nível Superior (CAPES) for financial.

\section{References}

Alvarez-Armas, I., \& Degallaix-Moreuil, S. (2009). Duplex Stainless Steels. Wiley.

Appleton, A. (2019). Microstructure Analysis for the Detection of Intermetallic Phases Predictive of Toughness and Corrosion Resistance in Duplex and Lean Duplex Steels. 100 Years of E04 Development of Metallographic Standards, 166-182.

Arturo, G. R. M., Hugo, L. M. V., Rafael, G. H., Egberto, B. B. \& Antonio, G. S. J. (2015). Electrochemical Characterization of AISI 2205 Duplex Stainless Steel Welded Joints with Electromagnetic Interaction. Procedia Materials Science, 8, 950-958.

Berecz, T., Fazakas, É., Mészáros, I. \& Sajó, I. (2015). Decomposition kinetics of ferrite in isothermally aged SAF 2507-type duplex stainless steel. Journal of Materials Engineering and Performance, 24(12), 4777-4788.

Cavalcanti, D. A., Muterlle, P. V. \& Reinke, G. (2019). Effect of Sigma Phase Precipitated at $850{ }^{\circ} \mathrm{C}$ on Corrosion Behaviour of UNS S82441 Duplex Stainless Steel. Matéria (Rio de Janeiro), 24(3), 1-11.

Chail, G. \& Kangas, P. (2016). Super and hyper duplex stainless steels: structures, properties and applications. Procedia Structural Integrity, 2 , $1755-1762$. 
Cronemberger, M. E. R. et al. (2014). Study of cooling rate influence on SAF 2205 duplex stainless steel solution annealed. Materials Science Forum, 802, $398-403$.

Cronemberger, M. E. R., Nakamatsu, S., Rovere, C. A. D., Kuri, S. E. \& Mariano, N. A. (2015). Effect of cooling rate on the corrosion behavior of As-Cast SAF 2205 duplex stainless steel after solution annealing treatment. Materials Research, 18(2), 138-142.

Dille, J. et al. (2017). Microstructural evolution during aging at $800{ }^{\circ} \mathrm{C}$ and its effect on the magnetic behavior of UNS S32304 lean duplex stainless steel. Journal of Magnetism and Magnetic Materials, 426, 102-107.

Haupt, W., Silva, L. E., Falcade, T., Santos, A. C. \& Reguly, A. (2019). Effect of ageing time on the toughness and the corrosion properties of duplex stainless steel UNS S31803. Materials Research, 22(6), 1-14.

Hilders, O. A., Zambrano, N. \& Ochoa, J. L. M. (2018). Microstructural evolution and mechanical property-fractal behavior relations of aged super duplex stainless steel. Original Research Article, 27(2), 83-107.

Jinlong, L., Tongxiang, L., Chen, W. \& Limin, D. (2015). Comparison of corrosion properties of passive films formed on coarse grained and ultrafine-grained AISI 2205 duplex stainless steels. Journal of Electro analytical Chemistry, 757, 263-269.

Kisasoz, A., Gurel, S. \& Karaaslan, A. (2016). Effect of Annealing Time and Cooling Rate on Precipitation Processes in a Duplex Corrosion-Resistant Steel. Metal Science and Heat Treatment, 57(9-10), 544-547.

Koche, J. C. (2011). Fundamentos de metodologia científica: Teoria da ciência e iniciação a pesquisa. Vozes.

Lacerda, J. C., Cândido, L. C. \& Godefroid, L. B. (2015). Effect of volume fraction of phases and precipitates on the mechanical behavior of UNS S31803 duplex stainless steel. International Journal of Fatigue, 74, 81-87.

Li, X., Lo, K. H., Kwok, C. T., Sun, Y. F. \& Lai, K.K. (2018). Post-fire mechanical and corrosion properties of duplex stainless steel: Comparison with ordinary reinforcing-bar steel. Construction and Building Materials, 174, 150-158.

Llorca-Isern, N., López-Jiménez, I., López-Luque, H., Biezma, M. V. \& Roca, A. (2016). Study of the Precipitation of Secondary Phases in Duplex and Superduplex Stainless Steel. Materials Science Forum, 879, 2537-2542.

Ludke, M. \& Andre, M. E. D. A. (2013). Pesquisas em educação: uma abordagem qualitativa. E.P.U.

Majid, M. \& Shahi, A. S. (2020). Influence of intermetallic precipitation on metallurgical, mechanical and pitting behavior of AISI 2205 duplex stainless steel welded joints. Materials Research Express, 6(12), 1-23.

Mandal, A. (2016). Processing-microstructure-microtexture-property correlation of Duplex Stainless Steels (Thesis). Indian Institute of Technology, Kharagpur, Indian.

Marques, I. J., Silva, F. J. \& Santos, T. F. A. (2020). Rapid precipitation of intermetallic phases during isothermal treatment of duplex stainless-steel joints produced by friction stir welding. Journal of Alloys and Compounds, 820, 153170.

Martins M. C. \& Hara L.C. (2004). Caracterização microestrutural e comportamento à corrosão do aço inox super duplex ASTM A890 GR 6A. In: 59 Congresso Anual da ABM.

Matias, J. V. S., Tavares, S. S. M., Pardal, J. M. \& Ribeiro, R. S. A. (2017). Embrittlement and Corrosion Decay of a Cast Duplex Stainless Steel. Materials Research, 20(2), 279-283.

Mehta, M., Jadhav, P., Shaikh, A., Kumar, S. \& Kirwai, S. (2019). Effect of Solution Treatment on Microstructure and Mechanical Properties of 2205 Duplex Stainless Steel. International Journal of Materials, Mechanics and Manufacturing, 7(6), 254-258.

Mohammed, A. M., Shrikrishna, K. A. \& Sathiya, P. (2016). Effects of post weld heat treatment on friction welded duplex stainless steel joints. Journal of Manufacturing Processes, 21, 196-200.

Morais, L. C \& Magnabosco, R. (2017). Experimental investigations and DICTRA® simulation of sigma phase formation in a duplex stainless steel. Calphad, $58,214-218$.

Nithin R. P., Sekar, K. \& Joseph, M. A. (2019). Effect of temperature on microstructure evolution and localized corrosion resistance of high tungsten hyper duplex stainless steel. Materials Research Express, 6(11), 116557.

Ogawa, K. \& Osuki, T. (2020). Modelling of Sigma Phase Precipitation in Super Duplex Stainless Steel Weld Metal. Isij International, 60(5), $1016-1021$.

Örnek, C., Burke, M., Hashimoto, T., Lim, J. \& Engelberg, D. (2017). $475^{\circ} \mathrm{C}$ Embrittlement of Duplex Stainless Steel - A Comprehensive Microstructure Characterization Study. Materials Performance and Characterization, 6(3), 409-436.

Örnek, C. \& Engelberg, D. 1. (2015). SKPFM measured Volta potential correlated with strain localization in microstructure to understand corrosion susceptibility of cold-rolled grade 2205 duplex stainless steel. Corrosion Science, 99, 164-171.

Paulraj, P. \& Garg, R. (2015). Effect of intermetallic phases on corrosion behavior and mechanical properties of duplex stainless steel and super-duplex stainless steel. Advances in Science and Technology Research Journal, 9, 87-105.

Pereira, A. S., Shitsuka, D. M., Parreira, F. J. \& Shitsuka, R. (2018). Metodologia da pesquisa científica UFSM.

Powar, A., Gujar, A., Manthani, N., Pawar, V. \& Singh, R. (2017). Effect of Secondary Phase Precipitation on Impact Toughness of Duplex Stainless Steel. Materials Science Forum, 889, 138-142. 
Research, Society and Development, v. 10, n. 8, e24910817369, 2021

(CC BY 4.0) | ISSN 2525-3409 | DOI: http://dx.doi.org/10.33448/rsd-v10i8.17369

Rezende, S. C., Dainezi, I., Apolinario, R. C., Sousa, L. L. \& Mariano, N. A. (2019). Influence of molybdenum on microstructure and pitting corrosion behavior of solution-treated duplex stainless steel in a lithium chloride solution. Materials Research, 22(1), 1-11.

Rezende, S.C. et al. (2018). Effect of solution annealing time on the microstructure and corrosion resistance of duplex stainless steel. Materials Science Forum, 930, 374-379.

Rivolta, B., Gerosa, R. \& Tavasci, F. (2018). The dilatometric technique for studying sigma phase precipitation kinetics in F55 steel grade. Journal of Thermal Analysis and Calorimetry, 132(2), 869-877.

Sáenz, L. et al. (2020). Duplex Stainless Steel Subjected to Normalized Thermal Treatment. Key Engineering Materials, 834, $103-109$.

Santos, D. C. \& Magnabosco, R. (2015). Kinetic Study to Predict Sigma Phase Formation in Duplex Stainless Steels. Metallurgical and Materials Transactions A, 47(4), 1554-1565.

Sicupira, D. C., Cardoso Junior, R., Bracarense, A. Q., Frankel, G. S. \& Lins, V. F. C. (2016). Electrochemical study of passive films formed on welded lean duplex stainless steel. Materials and Corrosion, 68(6), 604-612.

Silva, E. et al. (2016). Classification of Induced Magnetic Field Signals for the Microstructural Characterization of Sigma Phase in Duplex Stainless Steels. Metals, 6(7), 164-180.

Silva, R. et al. (2016). Effect of thermal aging at $475^{\circ} \mathrm{C}$ on the properties of lean duplex stainless steel 2101. Materials Characterization, $114,211-217$.

Valeriano, L. C., Correa, E. O., Mariano, N. A., Robin, A. L. M. \& Machado, M. A. G. T. C. (2019). Influence of the Solution-Treatment Temperature and Short Aging Times on The Electrochemical Corrosion Behaviour of Uns S32520 Super Duplex Stainless Steel. Materials Research, $22(4), 1-7$.

Verma, J. \& Taiwade, R. V. (2017). Effect of welding processes and conditions on the microstructure, mechanical properties and corrosion resistance of duplex stainless steel weldments A review. Journal of Manufacturing Processes, 25, 134-152.

Warren, A. D. et al. (2015). Quantification of sigma-phase evolution in thermally aged 2205 duplex stainless steel. Journal of Materials Science, 51(2), 694707.

Xiang, H., Liu, C., Deng, L. \& Zheng, K. (2019). Effect of Aging Temperature on the Microstructure and Properties of Economical Duplex Stainless Steel. Materials, 12(13), 2085.

Zeng, H., Yang, Y., Xu, R., Xin, S. \& Li, M. (2019). Pitting corrosion resistance of sensitized type 2205 duplex stainless steel in hot concentrated seawater. Journal of Solid State Electrochemistry, 23, 2793-2801.

Zhang, Z. et al. (2017). Influence of microstructure and elemental partitioning on pitting corrosion resistance of duplex stainless steel welding joints. Applied Surface Science, 394, 297-314. 